\title{
ANALISIS ECONOMIC VALUE ADDED (EVA) UNTUK \\ MENILAI KINERJA KEUANGAN PERUSAHAAN PADA PT VILLA AYU AMANDARI HOTEL UBUD GIANYAR
}

\author{
Ni Kadek Ayu Ari Astari Putri' ${ }^{1}$, Nyoman Dwika Ayu Amrita ${ }^{2}$ \\ 1,2Fakultas Ekonomi Universitas Ngurah Rai, Bali, Indonesia \\ Ni Kadek Ayu Ari Astari Putri1e-mail: astariputri97@gmail.com
}

\begin{abstract}
Abstrak: Penelitian ini bertujuan untuk mengetahui kinerja keuangan perusahaan pada PT. Villa Ayu Amandari Hotel Ubud Gianyar berdasarkan analisis economic value added (eva). Data yang digunakan dalam penelitan ini yaitu data sekunder mengenai laporan laba rugi dan neraca. Data dianalisis dengan menggunakan teknik analisis economic value added (eva). Hasil penelitian menunjukan nilai economic value added (eva) yang dihasilkan dari tahun 2016 sampai dengan tahun 2017 yaitu bernilai negatif atau Economic Value Added (EVA) kurang dari nol, sehingga bisa dikatakan kinerja keuangan perusahaan tidak baik.
\end{abstract}

Kata kunci: Economic Value Adedd (EVA); Kinerja Keuangan

Abstract: This study aims to determine the company's financial performance at PT. Villa Ayu Amandari Hotel Ubud in Gianyar Regency based on analysis of economic value added (eva). The data used in this study is secondary data regarding the income statement and balance sheet. Data analysis uses economic value added analysis techniques. The results show the value of economic value added (eva) produced from 2016 to 2017, which is negative or economic value added (eva) less than zero, so that it can be said that the company's financial performance is not good.

Keywords: Economic Value Adedd (EVA); Financial Performace

\section{PENDAHULUAN}

Dalam melaksanakan usahanya, pihak manajemen perusahaan memerlukan suatu alat pengukur untuk mengukur kinerja keuangan perusahaan. Menurut Irham Fahmi (2013:122) mendefinisikan bahwa kinerja keuangan merupakan gambaran dari pencapaian keberhasilan perusahaan dapat diartikan sebagai hasil yang telah dicapai atas berbagai aktivitas yang telah dilakukan.

Ukuran yang sering digunakan oleh suatu perusahaan untuk menilai kinerja keuangan perusahaan adalah dengan menggunakan analisis rasio keuangan. Akan tetapi, analisis rasio keuangan mempunyai kelemahan - kelemahan. Salah satu kelemahan kelamahan dari analisis rasio keuangan itu adalah kesulitan dalam memilih rasio yang tepat yang dapat digunakan untuk para pemangku kepentingan.

Bila menilai kinerja keuangan hanya dengan menggunakan rasio keuangan, itu hanya berorientasi pada laba (profit), akan tetapi pada saat ini perusahaan dituntut untuk tidak hanya berorientasi pada laba namun juga harus berorientasi pada nilai (value). Untuk mengatasi kelemahan - kelamahan tersebut maka digunakan analisis economic value added (eva).

Menurut (Sawir, 2015) mengatakan bahwa economic value added (eva) adalah ukuran yang dapat digunakan oleh banyak perusahaan untuk menentukan apakah suatu investasi yang diusulkan atau yang ada, dapat memberikan kontribusi yang positif terhadap 
kekayaan pemegang saham. Dari penjelasan tersebut dapat dikatakan bahwa economic value added (eva) adalah alat untuk mengukur kinerja keuangan perusahaan, yang mempertimbangkan harapan - harapan pemegang saham dan kreditur dengan cara mengurangkan laba operasi setelah pajak dengan biaya tahunan dari semua modal yang digunakan perusahaan.

PT. Villa Ayu Amandari Hotel adalah perusahaan yang bergerak dalam bidang jasa khususnya perhotelan atau akomodasi dan restoran yang berdiri pada 10 oktober 1989 . Adapun laporan laba (rugi) pada PT. Villa Ayu Amandari Hotel berdasarkan laporan keuangan dari tahun 2016 sampai dengan tahun 2017 dapat dilihat melalui tabel 1 berikut ini:

Tabel 1

Laporan Laba Rugi pada Perusahaan PT. Villa Ayu Amandari Hotel Tahun $2016-2017$

\begin{tabular}{cc}
\hline Tahun & Laba (Rugi) Perusahaan \\
\hline 2016 & Rp. (4.003.831.554) \\
\hline 2017 & Rp. (2.062.717.471) \\
\hline
\end{tabular}

Sumber: Laporan Laba Rugi PT. Villa Ayu Amandari Hotel

Dari tabel 1 yang merupakan laporan laba rugi perusahaan PT. Villa Ayu Amandari Hotel, meliputi pendapatan perusahaan, pengeluaran perusahaan, serta laba (rugi) perusahaan. Dari pendapatan dan pengeluaran yang diperoleh dan digunakan oleh perusahaan terus mengalami kerugian yaitu pada tahun 2016 sebesar Rp. (4.003.831.554) dan pada tahun 2017 mengalami kerugian sebesar Rp. (2.062.717.471).

Kerugian perusahaan secara terus menerus ini akan menjadikan perusahaan dinilai buruk dalam memperoleh laba dan dapat terjadi kebangkrutan. Dengan demikian analisis kinerja keuangan dibutuhkan untuk mengevaluasi kinerja perusahaan dari aspek keuangan dengan menggunakan analisis economic value added (eva). Penelitian ini bertujuan untuk mengetahui: kinerja keuangan perusahaan pada PT. Villa Ayu Amandari Hotel berdasarkan analisis economic value added (eva).

\section{METODE PENELITIAN}

Desain dalam penelitian ini bersifat analisis data kuantitatif di mana data tersebut dalam bentuk angka-angka yang dapat dihitung, yang diperoleh dari perkembangan laporan keuangan perusahaan yang akan diteliti yang berkaitan dengan masalah yang akan dibahas dalam penulisan ini.Teknik pengumpulan data yang digunakan dalam penelitian ini dilakukan dengan observasi, wawancara, dan studi dokumentasi. Teknik analisis data dalam penelitian ini menggunakan analisis economic value added (eva). Menurut (Rudianto, 2013) mengatakan bahwa langkah-langkah untuk mencari economic value added (eva) adalah sebagai berikut:

a. Menghitung Net Operating Profit After Tax (NOPAT)

Net Operating Profit After Tax (NOPAT) adalah laba yang diperoleh dari operasi perusahaan setelah dikurangi pajak penghasilan. Net Operating Profit After Tax (NOPAT) dapat dihitung dengan rumus sebagai berikut:

$$
\text { NOPAT = Laba (Rugi) }- \text { Beban Pajak }
$$

\section{b. Menghitung Invested Capital}

Invested capital adalah jumlah seluruh pinjaman diluar pinjaman jangka pendek tanpa bunga, seperti hutang dagang, biaya yang masih harus dibayar, utang pajak, uang 
muka pelanggan dan sebagainya. Invested capital dapat dihitung dengan rumus sebagai berikut:

c. Menghitung Weight Average Cost of Capital (WACC)

$$
\text { IC=Total Hutang dan Ekuitas - Hutang Jangka Pendek }
$$

Weight Average Cost of Capital (WACC) merupakan perhitungan biaya modal dari masing - masing komponen modal. Weight Average Cost of Capital (WACC) dapat dihitung dengan rumus sebagai berikut:

$$
\text { WACC }=\{((\mathrm{D} \times \mathrm{Rd}) \times(1-\mathrm{Tax})+(\mathrm{E} \times \mathrm{Re})\}
$$

\section{d. Menghitung Capital Charges}

Capital charges merupakan aliran kas yang dibutuhkan untuk mengganti para investor atas resiko usaha dari modal usaha yang diinvestasikan. Capital charges dapat dihitung dengan rumus sebagai berikut:

\section{Capital Charges $=$ WACC $\times$ Invested Capital}

\section{e. Menghitung Economic Value Added (EVA)}

Economic value added (Eva) sebagai alat pengukur kinerja keuangan didasarkan pada gagasan laba ekonomis yang menyatakan bahwa kekayaan hanya diciptakan ketika sebuah perusahaan mampu menutup biaya operasi dan biaya modal. Economic value added (Eva) dapat dihitung dengan rumus sebagai berikut:

\section{EVA=NOPAT - Capital charges}

\section{HASIL DAN PEMBAHASAN}

\section{Menghitung Net Operating Profit After Tax (NOPAT)}

Tujuan menghitung Net Operating Profit After Tax (NOPAT) adalah untuk mengetahui seberapa besar peningkatan laba bersih yang diperoleh dari laba operasi perusahaan setelah dikurangi pajak penghasilan.

Tabel 2

Hasil Net Operating Profit After Tax (NOPAT)

\begin{tabular}{cc}
\hline Tahun & NOPAT \\
\hline $\mathbf{2 0 1 6}$ & Rp. (3.942.826.229) \\
\hline $\mathbf{2 0 1 7}$ & Rp. (1.993.739.200) \\
\hline
\end{tabular}

Sumber: Data diolah menggunakan Excel, 2019

Dari Tabel 1 dapat dilihat bahwa nilai Asymp. Sig. (2-tailed) adalah 0,154. Nilai tersebut lebih besar dari 0,05 yang berarti dapat dikatakan bahwa data tersebut adalah berdistribusi normal. Hasil uji multikolinearitas dapat dilihat pada tabel 2.

Tabel 2

Hasil Uji Multikolinearitas

\begin{tabular}{lcc}
\hline Variabel Bebas & Tolerance & Nilai VIF \\
\hline Kualitas Tenaga Pemasar Kredit & 0,380 & 2,633 \\
\hline Pengendalian Internal Kredit & 0,380 & 2,633 \\
\hline
\end{tabular}

Sumber: Pengolahan Data Penelitian Pada Lampiran 
Berdasarkan perhitungan pada tabel 2 dapat dilihat bahwa nilai Net Operating Profit After Tax (NOPAT) PT. Villa Ayu Amandari Hotel pada tahun 2016 sebesar Rp. (3.942.826.229). Sedangkan pada tahun 2017 Net Operating Profit After Tax (NOPAT) menurun menjadi Rp. (1.993.739.200).

Hal ini disebabkan karena perusahaan mengalami kerugian dari Rp. (4.003.831.554) pada tahun 2016 menjadi Rp. (2.062.717.471) pada tahun 2017. Dimana Hal tersebut sangat berpengaruh terhadap nilai Economic Value Added (EVA) perusahaan, dimana jika kinerja manajemen baik maka akan terlihat pada Net Operating Profit After Tax (NOPAT) yang dapat menutupi biaya modal yang diinvestasikan sehingga menciptakan nilai tambah ekonomi bagi perusahaan.

\section{Menghitung Invested Capital (IC)}

Tujuan menghitung Invested Capital (IC) adalah untuk mengetahui seluruh jumlah pinjaman perusahaan diluar pinjaman jangka pendek.

\section{Tabel 3}

Hasil Invested Capital (IC)

\begin{tabular}{cl}
\hline Tahun & Invested Capital \\
\hline $\mathbf{2 0 1 6}$ & Rp. 10.227.502.701 \\
\hline $\mathbf{2 0 1 7}$ & Rp. 7.939 .745 .805 \\
\hline
\end{tabular}

Sumber: Data diolah menggunakan Excel, 2019

Berdasarkan perhitungan pada tabel 3 dapat dilihat bahwa nilai Invested Capital PT. Villa Ayu Amandari Hotel pada tahun 2016 yaitu sebesar Rp. 10.227.502.701. Sedangkan nilai Invested Capital untuk tahun 2017 mengalami penurunan menjadi Rp. 7.939.745.805. Dalam penjelesan tersebut menunjukkan bahwa total modal yang diinvestasikan di tahun 2016 sampai dengan tahun 2017 mengalami penurunan penurunan tersebut disebabkan karena menurunnya jumlah pinjaman dan ekuitas.

\section{Menghitung Weight Average Cost of Capital (WACC)}

Tujuan menghitung biaya modal dari masing - masing komponen modal Dimana rata-rata biaya utang dan modal menggambarkan tingkat pengembalian investasi minimum untuk mendapatkan tingkat pengembalian yang diharapkan oleh para investor.

Tabel 4

Hasil Weight Average Cost of Capital (WACC)

\begin{tabular}{cc}
\hline Tahun & (WACC) \\
\hline 2016 & $-12.48 \%$ \\
\hline 2017 & $-8.45 \%$ \\
\hline
\end{tabular}

Sumber: Pengolahan Data Penelitian Pada Lampiran

Berdasarkan perhitungan pada tabel 4 dapat dilihat bahwa Weighted Average Cost of Capital (WACC) PT. Villa Ayu Amandari Hotel pada tahun 2016 yaitu sebesar -12,48\%. Sedangkan Weighted Average Cost of Capital (WACC) untuk tahun 2017 mengalami penurunan menjadi $-8.45 \%$. Berdasarkan uraian diatas terlihat bahwa perusahaan belum mampu mengembalikan tingkat pengembalian investasi ke para pemegang saham (investor). 
4. Menghitung Capital Charges (CC)

Capital charges menunjukkan seberapa besar modal yang telah diinvestasikan ke dalam perusahaan oleh kreditur dan pemegang saham.

Tabel 5

Hasil Capital Charges (CC)

\begin{tabular}{cc}
\hline Tahun & Capital Charges \\
\hline $\mathbf{2 0 1 6}$ & Rp. (1.276.392.337) \\
\hline $\mathbf{2 0 1 7}$ & Rp. $(670.908 .521)$ \\
\hline
\end{tabular}

Sumber: Data diolah menggunakan Excel, 2019

Berdasarkan perhitungan pada tabel 5 dapat dilihat bahwa nilai Capital Charges yang dihasilkan pada tahun 2016 sebesar Rp. (1.276.392.337). Sedangkan pada tahun 2017 mengalami penurunan menjadi Rp. (670.908.521).

Capital charges, invested capital dan Weighted Average Cost of Capital (WACC) saling berkaitan, apabila Weighted Average Cost of Capital (WACC) dan invested capital menurun setiap tahunnya maka akan berdampak pada capital charges. Sehingga modal yang diinvestasikan dalam perusahaan setiap tahun menurun dikarenakan tingkat pengembalian investasi yang diterima investor menurun.

\section{Menghitung Economic Value Added (EVA)}

Tujuan menghitung economic value added (eva) untuk mengukur kinerja keuangan didasarkan pada gagasan laba ekonomis yang menyatakan bahwa kekayaan hanya diciptakan ketika sebuah perusahaan mampu menutup biaya operasi dan biaya modal.

Tabel 6

Hasil Economic Value Added (EVA)

\begin{tabular}{cc}
\hline Tahun & (EVA) \\
\hline $\mathbf{2 0 1 6}$ & $\operatorname{Rp}(2.666 .433 .892)$ \\
\hline $\mathbf{2 0 1 7}$ & $\operatorname{Rp}(1.322 .830 .679)$ \\
\hline
\end{tabular}

Sumber: Data diolah menggunakan Excel, 2019

Berdasarkan hasil perhitungan pada tabel 6 dapat dilihat bahwa nilai Economic Value Added (EVA) yang dihasilkan pada perusahaan PT. Villa Ayu Amandari Hotel pada tahun 2016 adalah Rp. (2.666.433.892). Nilai Economic Value Added (EVA) pada tahun 2016 menunjukan nilai yang negatif. Kemudian pada tahun 2017 nilai Economic Value Added (EVA) kembali negatif yaitu sebesar Rp. (1.322.830.679).

Dari penjelasan tersebut nilai Economic Value Added (EVA) yang dihasilkan dari tahun 2016 sampai dengan tahun 2017 yaitu bernilai negatif atau Economic Value Added (EVA) kurang dari nol. Hal ini disebabkan karena perusahaan tidak mampu menghasilkan tingkat kembalian laba operasi setelah pajak yang melebihi biaya modal.

Sehingga dapat dikatakan bahwa pada tahun tersebut tidak terjadi proses nilai tambah ekonomis atau tidak adanya penciptaan nilai karena laba yang tersedia tidak memenuhi harapan para penyandang dana terutama pemegang saham yaitu tidak mendapatkan pengembalian yang setimpal dengan investasi yang sudah ditanamkan, sehingga bisa dikatakan kinerja keuangan perusahaan tidak baik. 


\section{KESIMPULAN}

Berdasarkan hasil analisis data dan pembahasan, maka di dapat kesimpulan hasil penelitian pada PT. Villa Ayu Amandari Hotel Ubud Gianyar. Nilai Economic Value Added (EVA) yang dihasilkan dari tahun 2016 sampai dengan tahun 2017 yaitu bernilai negatif atau Economic Value Added (EVA) kurang dari nol. Hal ini disebabkan karena perusahaan tidak mampu menghasilkan tingkat kembalian laba operasi setelah pajak yang melebihi biaya modal.

Sehingga dapat dikatakan bahwa pada tahun tersebut tidak terjadi proses nilai tambah ekonomis karena laba yang tersedia tidak memenuhi harapan para penyandang dana terutama pemegang saham yaitu tidak mendapatkan pengembalian yang setimpal dengan investasi yang sudah ditanamkan, sehingga bisa dikatakan kinerja keuangan perusahaan tidak baik.

\section{SARAN}

Dalam usaha lebih meningkatkan kinerja keuangan maka dapat disarankan bagi manajemen PT. Villa Ayu Amandari Hotel Ubud Gianyar sebagai berikut:

a. Bagi Perusahaan

Untuk Economic Value Added (EVA) yang bernilai negatif, hendaknya manajemen perusahaan melakukan pengawasan terhadap biaya modal yang digunakan karena biaya modal menunjukkan besarnya pengembalian yang dituntut oleh investor atas modal yang diinvestasikan ke dalam perusahaan.

b. Bagi Peneliti Selanjutnya

Diharapkan dapat menggunakan rentang waktu penelitian serta data kinerja perusahaan yang lebih banyak dan bisa menambahkan variabel lain yang dapat mempengaruhi kinerja perusahaan.

\section{UCAPAN TERIMAKASIH}

Ucapan terima kasih penulis sampaikan kepada seluruh narasumber yang bersedia membantu dan memberikan informasi yang diperlukan pada penelitian ini. Ucapan terima kasih juga kami sampaikan kepada para pihak yang membantu dalam selesainya tulisan ini.

\section{REFERENSI}

Abdullah, Muhammad. Faisal.(2014). Dasar - Dasar Manajemen Keuangan. Edisi 4. Malang: Universitas Muhammadiyah.

Dwihandoko, Toto. Heru. (2017). Metode Economic Value Added Sebagai Alternatif untuk Mengukur Kinerja Perusahaan Pada PT. Citra Utama Barokah. Majalah Ekonomi_ISSN No.1411-9501_Vol.XXII No.2.

Fahmi, Irham. (2013). Analisis Laporan Keuangan. Bandung: Alfabeta.

Gandhi, S.dkk. (2015). Analisis Rasio Likuiditas, Solvabilitas, Profitabilitas, dan Metode Economic Value Added Hotel Sunari Villa \& SPA. e- Journal Bisma Universitas Pendidikan Ganesha Singaraja JurusanManajemen Volume 3 Tahun 2015.

Harahap, Sofyan. Syafri. (2013). Analisis Kritis Atas Laporan Keuangan. Jakarta: Rajawali Pers. 
Harjito, Agus. dan Martono. (2013). Manajemen Keuangan. Edisi 2. Yogyakarta: Ekonisa.

Horne, Van. dan Wachowicz. (2013). Prinsip - prinsip Manajemen Keuangan. Edisi Indonesia. Jakarta: Salemba Empat.

Kasmir. (2014). Analisis Laporan Keuangan, Edisi 1 Jilid1. Jakarta: PT. Rajagrafindo Persada.

Miten, F. K.dkk. (2013). Analisis Kinerja Keuangan Perusahaan Kopi Bubuk PD. Ayam Ras Kota Jambi dengan Metode Economic Value Added. Sosio Ekonomi Bisinis Vol.16. (2) 2013.

Munawir. (2014). Analisis Laporan Keuangan. Yogyakarta: Liberty.

Much, Nurachmad. (2014). Segala Tentang HAKI Indonesia. Yogyakarta: Buku Biru.

Rudianto, E. (2013). Akuntansi Manajemen Informasi Untuk Pengambilan Keputusan Strategis. Jakarta: Erlangga.

Sartono, Agus. (2014). Manajemen Keuangan: Teori dan Aplikasi. Edisi Keempat. Yogyakarta: BPFE.

Sawir, A. (2015). Analisis Kinerja Keuangan dan Perencananaan Keuangan Perusahaan. Gramedia Pustaka.

Sugiyono. (2017). Metodelogi Penelitian Kuantitatif, Kualitatif, dan RED. Bandung: Alfabeta.

Sumarni, Murti. dan John Soeprihanto. (2010). Pengantar Bisnis (Dasar - dasar Ekonomi Perusahaan). Edisi Kelima. Yogyakata: Penerbit Libert.

Winarno, Slamet. Heri. (2014). Analisis Penilaian Kinerja Keuangan Menggunakan Penerapan Economic Value Added (Studi Kasus: Pada PT. Binaartha Parama Jakarta). Moneter, Vol. I No. 2 